\title{
Speech peculiarities of American political pre-election discourse
}

\author{
T. Zabolonta
}

\author{
SHEI «Pereiaslav-Khmelnytskyi state pedagogical Hryhorii Skovoroda university» \\ Corresponding author. E-mail: taniazab@gmail.com
}

Paper received 26.03.20; Accepted for publication 19.04.20.

\section{https://doi.org/10.31174/SEND-Ph2020-225VIII67-15}

Abstract. This article describes the main peculiarities of the U.S. pre-election political discourse and linguistic analysis of the texts which American politicians have declared in their campaign speeches has been researched. The material of the research was taken from pre-election speeches of D. Trump and H. Clinton. According to the study the definition of pre-election discourse was given and the main morphological, lexical and grammatical peculiarities of the campaign speech texts were identified.

Keywords: political discourse; pre-election discourse; linguistic analysis; political language; language; linguistics.

Now we can see a growing interest in the study of political discourse. The study of campaign texts is the most interesting and relevant aspect to study, since the creation of such texts uses various linguistic means, the purpose of which is to create and form a certain public opinion, as well as to encourage voters to take an elective decision.

The concept of political discourse has been explored by many researchers. Two main definitions of this term have been formed. In a monograph, E.I. Sheigal states that this term means any speech entity, subject, or addressee, the content of which belongs to the sphere of politics [2].

A narrower definition of political discourse is also held by the Dutch linguist T. van Dyck. In his opinion, "political discourse is a class of genres limited by the social sphere, namely politics. Government debates, parliamentary debates, party programs, and speeches of politicians are the genres that belong to the sphere of politics" [1].

The purpose of political discourse is to seize, retain or redistribute power. While studying the tests of the election campaigns, one cannot help mentioning the election discourse. Pre-election political discourse is a speech genre, which is a complex of communicative events and at the same time a verbal form of this communicative event, and has a certain role and composition of participants, which is distinguished by publicity and official bodies.

The main objective of pre-election political discourse is to inspire the addressees to take "politically correct" actions. The texts of pre-election political discourse have the following features: 1) logicality; 2) figurativeness; 3) emotionality; 4) evaluativness; 5) appeal.

These texts are characterized by a wide use of sociopolitical vocabulary, figurative means, figurative meaning of words, words with bright emotional coloring.

The syntax of this style of speech is characterized by the use of homogeneous members, introductory words and sentences, complex syntactic constructions.

The materials of the study are the texts of election speeches of American politicians H. Clinton and D. Trump.

The main method of research is the method of complex analysis to determine the lexical and grammatical features of the text.

The high percentage of adjectives, adverbs and participles is observed in Hillary Clinton's speeches. "Too many black Americans, especially young men, feel like their lives are disposable. And they worry every single day about what might happen" [4].

In Hillary Clinton's speech there are many adjectives in comparative degree, which serve to highlight certain qualities. "You know that in many states, childcare is more expensive than rent, it's more expensive even than college tuition" [4].

Donald Trump's speeches, on the contrary, are distinguished by the frequent use of adjectives and adverbs in superlative degree. "Our system of government, and our American culture, are the best in the world and will produce the best for all who adopt it" [7]. "This is my pledge to the American people: as your President I will be your greatest champion" [7].

The use of modal verbs in the speeches of these politicians is also indicative. In particular, Hillary Clinton's speeches are highlighted by the modal verb "can" which is commonly used in her speeches, and modal verbs "should" and "may" are also found. "We may disagree about how to do these things, but surely we can all agree with those basic premises" [4]. "And that can have devastating consequences" [4]. "I believe the federal government should adopt five goals" [5].

At the same time, the verb "must" is hardly found in her speeches. This can be explained by the general orientation of her speech towards the logical, reasons but not categorical belief.

In Donald Trump's speeches, the modal verb "must" is the most often used one, which gets a rather categorical coloring due to the fact that it is often used in rhetorical questions, in repetitions, in sentences where it is included in the ranks of homogeneous members of the sentence, and in combination with reinforcement structures. "But to achieve this future, we must break free from the bitter failures of the past - and reject the same insiders telling us the same old lies" [6].

This modal verb is most commonly used in sentences where the subject is a personal pronoun "we". "But we must also talk about those who have been left behind, the millions suffering in disastrous conditions in so many of our inner cities - and neighborhoods afflicted by poverty, drugs, and violence" [8].

Among the lexical features of these speeches we should also mention the use of antonyms and synonyms. Their functions in the text are quite different. Let us consider how Hillary Clinton uses antonyms and synonyms in his speeches. "And in times like these, we need a President who can help pull us together, not split us apart" [3]. In this case, the antonyms create an opposition that is 
built on expressions that act as homogenous members of the sentence.

In Donald Trump's speeches, antonyms are also used to create opposites, often in parallel syntactic constructions. "It will do so by emphasizing what we have in common not what pulls us apart" [6].

It should also be noted that Hillary Clinton's speeches are characterized by the use of phraseology. This increases the imagery and expressiveness of her speeches. "It means embracing policies that promote justice for all people, and standing firm against any attempt to roll back the clock on the rights and opportunities that so many sacrificed so much to secure" [4]. "Let's put ourselves in the shoes of police officers, kissing their kids and spouses goodbye every day and heading off to a dangerous job we need them to do" [4].
We can also note the peculiarity of Donald Trump's speeches at the lexical level. In the lexicon there is a frequent use of lexical units with prefix re, which emphasizes the general meaning of the speech - to recreate, restore a country, to return what has already happened: "This will require rethinking the failed policies of the past" [6]. "We can make new friends, rebuild old alliances, and bring new allies into the fold" [8].

Thus, the introductory words serve to indicate the degree of accuracy of information, the order in which statements are presented, the attitude towards the statement. In order to increase the expressiveness of their speech, politicians used adjectives in comparative and superior degree, rhetorical question sentences, complex sentences, on the basis of which emotionality and pathos of speech were increased

\section{LITERATURE}

1. Дейк Т. А. ван. Язык. Познание. Коммуникация. М.: Прогресс, 1989. 312 с.

2. Шейгал Е. И. Семиотика политического дискурса. М.: Гнозис, 2004. 324 с

3. Hillary Clinton. Remarks on building an economy that works for everyone.

URL: https://www.hillaryclinton.com/post/remarks-buildingeconomy-works-everyone.

4. Hillary Clinton. Remarks on American Values. URL: https://www.hillaryclinton.com/post/remarksamerican-values/

5. Hillary Clinton.Hillary Clinton Rejects Trump's Vision for America and Vows to Fight for All Hardworking Families. URL:

https://www.hillaryclinton.com/briefing/updates/2016/05/25/ hillaryclinton-rejects-trumps-vision-for-america-and-vows-

to-fight-for-all-hardworking-families/

6. Donald Trump. Hillary's Tpp would be Deathknell for American Manufacturing. URL: https://www.donaldjtrump.com/press-releases/donald-j.trump-remarks-in-novi-michigan

7. Donald Trump. Party of Lincoln Promises Hope to Every Forgotten Stretch of America. URL: https://www.donaldjtrump.com/press-releases/trump-partyof-lincoln-promises-hope-to-everyforgotten-stretch-ofamerica

8. Donald Trump. Transcript of Donald Trump's speech on national security in Philadelphia. URL: http://thehill.com/blogs/pundits-blog/campaign/294817transcript-of-donald-trumps-speech-on-nationalsecurity-in

\section{REFERENCES}

1. Dejk T. A. Language. Perception. Communication. M.: Progress, 1989. $312 \mathrm{p}$.

2. Sheigal E. I. Semiotics of political discourse.. M.: Gnosis, 2004. $324 \mathrm{p}$.

3. Hillary Clinton. Remarks on building an economy that works for everyone.

URL: https://www.hillaryclinton.com/post/remarks-buildingeconomy-works-everyone.

4. Hillary Clinton. Remarks on American Values. URL: https://www.hillaryclinton.com/post/remarksamerican-values/

5. Hillary Clinton.Hillary Clinton Rejects Trump's Vision for America and Vows to Fight for All Hardworking Families. URL:

https://www.hillaryclinton.com/briefing/updates/2016/05/25/ hillaryclinton-rejects-trumps-vision-for-america-and-vows- to-fight-for-all-hardworking-families/

6. Donald Trump. Hillary's Tpp would be Deathknell for American Manufacturing. URL: https://www.donaldjtrump.com/press-releases/donald-j.trump-remarks-in-novi-michigan

7. Donald Trump. Party of Lincoln Promises Hope to Every Forgotten Stretch of America. URL: https://www.donaldjtrump.com/press-releases/trump-partyof-lincoln-promises-hope-to-everyforgotten-stretch-ofamerica

8. Donald Trump. Transcript of Donald Trump's speech on national security in Philadelphia. URL: http://thehill.com/blogs/pundits-blog/campaign/294817transcript-of-donald-trumps-speech-on-nationalsecurity-in 